\title{
Quality Enhancement of Aceh Swamp Buffalo (Bubalus bubalis) Frozen Semen by Supplementing $\beta$-Carotene
}

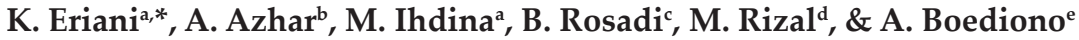 \\ aDepartment of Biology, Faculty of Mathematics and Natural Sciences, Syiah Kuala University \\ Jalan Syech Abdul Rauf, No. 3, Banda Aceh 23111, Indonesia \\ ${ }^{b}$ Faculty of Veterinary Medicine, Syiah Kuala University \\ Jalan Tgk Hasan Krueng Kalee No.4, Banda Aceh 23111, Indonesia \\ 'Department of Animal Reproduction, Faculty of Animal Science, Jambi University \\ Mendalo Jambi 36361, Indonesia \\ ${ }^{\mathrm{d}}$ Department of Animal Science, Faculty of Agriculture, Lambung Mangkurat University \\ Jalan Jendral Ahmad Yani Km 36, Banjarmasin 70714, Indonesia \\ e Department of Anatomy, Physiology and Pharmacology, Faculty of Veterinary Medicine, \\ Bogor Agricultural University \\ Jalan Rasamala Kampus Dramaga, Bogor 16680, Indonesia \\ *Email of corresponding author: kartini_eriani@unsyiah.ac.id \\ (Received 24-11-2017; Reviewed 21-12-2017; Accepted 19-01-2018)
}

\begin{abstract}
Sperms are vulnerable to oxidative stress due to the high proportion of polyunsaturated fatty acids within their membranes. This condition could decrease sperms quality during preservation. $\beta$-carotene is among antioxidants able to neutralize reactive oxygen species, natural by-products of oxygen metabolism in sperms. This study was done to investigate the capability and protective effect of this antioxidant on motility, viability, acrosomal integrity, and plasma membrane integrity of frozen-thawed sperms of Aceh swamp buffalo. The study was conducted using completely randomized design with four treatments and five replications. Fresh semen was diluted in egg-yolk tris-based extenders with the addition of antioxidant of $0 \%(\mathrm{w} / \mathrm{v})$ (control, P0), $0.625 \%(\mathrm{w} / \mathrm{v})(\mathrm{P} 1), 1.25 \%(\mathrm{w} / \mathrm{v})(\mathrm{P} 2)$, and $2.5 \%(\mathrm{w} / \mathrm{v})(\mathrm{P} 3)$ prior to freezing. Variables of sperms quality examined were motility, viability, acrosomal integrity, and plasma membrane integrity of semen after dilution, equilibration, and thawing. Semen having the best post-thawing quality after $\beta$-carotene treatment was used for artificial insemination (AI) for accessing its pregnancy rate. The results showed that the addition of $0.625 \%(\mathrm{w} / \mathrm{v})$ $\beta$-carotene (P1) resulted in the highest motility, viability, acrosomal integrity, and plasma membrane integrity. Pregnancy rate of buffalo inseminated with semen treated with $0.625 \% \beta$-carotene (P1) was $50 \%$. In conclusion, administration of $0.625 \% \beta$-carotene was able to maintain and could protect motility, viability, acrosomal integrity, and plasma membrane integrity of frozen sperms of Aceh swamp buffalo that are good for artificial insemination.
\end{abstract}

Keywords: Aceh swamp buffalo, frozen semen, antioxidant, $\beta$-carotene, thawing

\section{INTRODUCTION}

Swamp buffalo (Bubalus bubalis) have been domesticated by peoples in developing countries for fulfilling the need for red meats and draught power (Cruz, 2007). Swamp buffalo are well-adapted to harsh environments and capable of utilizing low quality roughages such as agricultural crop-residues and by-products (Wanapat \& Chanthakhoun, 2015). Unfortunately, the animals also suffer from low reproductive efficiency and are hampered by female buffalo inherit late maturity, poor estrous expression, distinct seasonal reproductive patterns, and prolonged inter-calving intervals (Singh et al., 2000).
Aceh swamp buffalo is one out of seven species that can be found in Indonesia. Despite of an increase in population in Aceh Province, from 171.747 heads in 2015 to 178.392 heads in 2016 (BPS, 2016), it is well known that the quality of Aceh swamp buffalo varies across the province. Therefore, selection of high-quality bulls is a necessary. Indonesian government, through the Ministry of Agriculture, has been developing Artificial Insemination (AI) program and technique to resolve this problem. However, the successful rate of this technology is still relatively low.

Application of AI with frozen-thawed semen is limited in buffalo due to a poor freezability of spermatozoas obtained from buffalo bull compared to that of 
cattle bull (Kumaresan et al., 2005). Spermatozoa must remain intact and plasma membrane should be in a good condition during freezing and thawing process (Marti et al., 2003). Cryopreservation and thawing, unfortunately, might result in a damage in the plasma membrane of spermatozoa and then reduces their post-thawing motilities and viabilities (Holt, 2000). This condition is in part due to the increased production of reactive oxygen species (ROS) (Bucak et al., 2010a). Sperms are vulnerable to oxidative stress due to the high proportion of polyunsaturated fatty acids within their membranes (Almbro et al., 2011) that might lead to oxidative damage of cell membranes, RNA, and DNA in the cells (Wang et al., 2003). The most significant effect of ROS on spermatozoa occurs following the ionophoreinduced acrosome reaction and subsequent production of singlet oxygen species, leading to lipoperoxidation (LPO) (Ting-xi et al., 2016). Oxidative stress from defective antioxidant defense may be responsible for the decreased sperms quality during preservation (Bansal \& Bilaspuri, 2011).

Sperms suffer from the decreased motility and membrane integrity when the semen was preserved in low temperature that may lead to a low conception rate, shorter sperm survival time in female reproductive tracts, reduced fertility, and increased embryonic loss (Kasimanickam et al., 2007). One of efforts conducted to solve this problem is antioxidant treatments of sperms during preservation. Previous studies showed that exogenous antioxidant treatments improved the vitality and motility of sperms in bulls (Sariözkan et al., 2009) and rams (Asadpour et al., 2012; Fang et al., 2015). A study by et al. (1993) reported that $\beta$-carotene could reduce destructive ability of oxygen singlet by physically accepting energy from the electron-rich structure of reactive oxygen species. However, it is not clear how $\beta$-carotene can enhance the viability of sperms. Thus, this study was aimed to investigate the capability and protective effect of $\beta$-carotene on the motility, viability, acrosomal integrity, and plasma membrane integrity of frozen-thawed sperms of Aceh swamp buffalo. The supplementation of $\beta$-carotene in tris base extenders is expected to improve the quality of frozen-thawed sperms of Aceh swamp buffalo.

\section{MATERIALS AND METHODS}

\section{Semen Collection and Cryopreservation}

Freshly ejaculated semen, around 3-5 mL, was collected from five 3.5-years-old male Aceh swamp buffalo at 08.00 in the morning and separately subjected to macroscopic examinations of color, volume, $\mathrm{pH}$, smell, and consistency as well as for microscopic examinations of mass, motility, viability, and abnormality. Semen used for cryopreservation should have standard quality of motility $\geq 70 \%$, sperm concentration $\geq 800.10^{6}$ cells $\mathrm{mL}^{-1}$. and abnormality $<15 \%$. Egg yolk tris-based extenders used were supplemented with $120 \mathrm{nM}$ lactose (cat. no: 1.05323.0250, Merck KgaA-Germany) and 7\% glycerol (Merck, Germany, cat. K28328694 044), to have better sperms protection (Eriani et al., 2017a). The concentra- tions of $\beta$-carotene (cat: 217538-1GM, Merck-USA) used in this study were $0 \%(\mathrm{w} / \mathrm{v})$ (Control, P0), $0.625 \%(\mathrm{w} / \mathrm{v})$ $(\mathrm{P} 1), 1.25 \%(\mathrm{w} / \mathrm{v})(\mathrm{P} 2)$, and 2.5\% (w/v) (P3). Equilibration time of semen sample was determined according to the procedure by Eriani et al. (2017b). The collected semen was frozen based on the method of Sarsaifi et al., (2013). Briefly, the collected semen was filled into 0.25 $\mathrm{mL}$ straws (Minitub GmbH-Germany) that approximately contained 50 millions of motile sperms. Twenty straws were usually prepared from 3-5 mL diluted ejacutales. The straws were stored in a $5{ }^{\circ} \mathrm{C}$ refrigerator (Thermoscientific- USA) for four hours before being transferred to a box filled with liquid nitrogen, $5 \mathrm{~cm}$ above the liquid nitrogen surface for 15 minutes, and plunged in liquid nitrogen $\left(-196^{\circ} \mathrm{C}\right)$.

\section{Evaluation of Frozen-Semen Thawing}

Finally, frozen semen was thawed in a $37^{\circ} \mathrm{C}$ waterbath (Memmerth, Germany) for 30 seconds and assessed for motility, viability, acrosomal integrity, and plasma membrane integrity (Fang et al., 2015).

Assessment of sperm viability. The smear of sperm suspension were prepared by mixing a drop of sperm sample with two drops of Eosin staining solution $(1.40 \%$ eosin-B (Merck, Germany), and 2.53\% sodium citrate (cat. no: 1.00244.0500, Merck KGaA-Germany) in distilled water on a warm glass slide and spreading it with a second slide and observed using a stereomicroscope (Olympus CKX41-Japan). Sperms displaying partial or full purple color were considered as nonviable.

Determination of acrosome integrity. Semen samples, $100 \mu \mathrm{L}$, were fixed in $500 \mu \mathrm{L}$ of $1 \%$ formal citrate solution $(2.79 \%$ trisodium citrate dihydrate (Merck, Germany) and $0.37 \%$ formaldehyde (cat no: 1.04003.1000, Merck kGaA, Germany) in distilled water). Acrosomes of 200 spermatozoa were microscopically examined using immersion oil (Olympus-Japan) at 1000 times magnification. The integrity of each acrosome was determined by the presence of normal pical ridge.

Assessment of plasma-membrane integrity. Hypoosmotic swelling test (HOST) was used to assess the integrity of sperm plasma membrane. In brief, $50 \mu \mathrm{L}$ of semen were incubated in $300 \mu \mathrm{L}$ of hypo-osmotic solution (2.04\% fructose (cat. no: 1.05323.0250, Merck KgaA-Germany) and $0.71 \%$ sodium citrate (cat. no: 1.00244.0500, Merck KGaA-Germany) in distilled water) at $37^{\circ} \mathrm{C}$ for 60 minutes. Then, a $100 \mu \mathrm{L}$ drop of mixtures was spread on a warm slide with a coverslip, and 200 sperms were microscopically evaluated under 1000 times magnification. The morphology of sperms (normal tails versus swollen or coiled tails) was recorded.

\section{Artificial Insemination}

Frozen semen of Aceh swamp buffalo that showed the best post-thawing semen quality were used to inseminate ten female buffaloes. Pregnancy diagnosis was determined 60 days post AI by per rectal palpation. 


\section{Statistical Analysis}

Variables for quality of freshly ejaculated semen namely color, volume, $\mathrm{pH}$, smell, and consistency as well as mass, motility, viability, and abnormality were evaluated only once for each semen to check if it fulfill standard quality for cryopreservation, and no further analysis was made. Data on post-thawing motility, viability, acrosomal integrity, and plasma membrane integrity were presented as means \pm deviation standard and then analyzed by analysis of variance using SPSS 23 for Windows. Differences between treatments were considered statistically significant at $\mathrm{P}<0.05$.

\section{RESULTS}

The quality of fresh semen of Aceh swamp buffalo is presented in Table 1. Results suggested that the collected semen of Aceh swamp buffalo met the standard for cryopreservation: motility $\geq 70 \%$, sperm concentration $\geq 800.10^{6}$ cells $\mathrm{mL}^{-1}$ and abnormality $<15 \%$ (Rizal, 2005). Results on motility, viability, acrosomal integrity, and membrane integrity of diluted, equilibrated, and post-thawed sperms of Aceh water buffalo treated with various concentrations of antioxidant ( $\beta$-carotene) can be found in Tables 2, 3, 4, and 5, respectively.

Table 1. Macroscopic and microscopic variables of fresh semen of buffalo

\begin{tabular}{lcc}
\hline Variables & $\mathrm{N}$ & Score/value \\
\hline Volume $(\mathrm{mL})$ & 5 & $1.16 \pm 0.21$ \\
Color & 5 & Milky white \\
$\mathrm{pH}$ & 5 & $6.8-7.0$ \\
Consistency & 5 & Medium \\
Concentration $\left(10^{6} / \mathrm{mL}\right)$ & 5 & $1267 \pm 2.60$ \\
Mass movement & 5 & +++ \\
Motility $(\%)$ & 5 & $81.8 \pm 2.49$ \\
Viability $(\%)$ & 5 & $90.2 \pm 5.18$ \\
Abnormality $(\%)$ & 5 & $10.2 \pm 1.92$ \\
\hline
\end{tabular}

Note: $(+++)=$ Mass movement of spermatozoa like waves; $\mathrm{N}=$ number of sample.

Table 2. Average motility (\%) of sperms of Aceh swamp buffalo treated with various concentrations of $\beta$-carotene at different phases of semen processing

\begin{tabular}{ccccc}
\hline \multirow{2}{*}{ Treatments } & N & \multicolumn{3}{c}{ Phases of semen processing } \\
\cline { 3 - 5 } & & Dilution & Equilibration & $\begin{array}{c}\text { Post } \\
\text { thawing }\end{array}$ \\
\hline P0 & 5 & $67.0 \pm 2.73^{\mathrm{a}}$ & $50.0 \pm 2.20^{\mathrm{a}}$ & $42.6 \pm 4.08^{\mathrm{c}}$ \\
P1 & 5 & $70.0 \pm 3.54^{\mathrm{a}}$ & $61.6 \pm 3.13^{\mathrm{b}}$ & $50.2 \pm 4.08^{\mathrm{d}}$ \\
P2 & 5 & $70.0 \pm 3.54^{\mathrm{a}}$ & $58.0 \pm 2.90^{\mathrm{b}}$ & $37.4 \pm 3.73^{\mathrm{b}}$ \\
P3 & 5 & $68.6 \pm 2.89^{\mathrm{a}}$ & $60.8 \pm 3.89^{\mathrm{b}}$ & $10.5 \pm 5.10^{\mathrm{a}}$ \\
\hline
\end{tabular}

Note: Means in the same column with different superscripts differ significantly $(\mathrm{P}<0.05) . \mathrm{P} 0=0 \% \beta$-carotene $(\mathrm{w} / \mathrm{v}) ; \mathrm{P} 1=0.625 \% \beta$-carotene $(\mathrm{w} / \mathrm{v}), \mathrm{P} 2=1.25 \% \beta$-carotene $(\mathrm{w} / \mathrm{v}) ; \mathrm{P} 3=2.5 \% \beta$-carotene $(\mathrm{w} / \mathrm{v})$. $\mathrm{N}=$ number of sample.
This study confirmed that cryopreservation process significantly reduced sperms motility of Aceh swamp buffalo as indicated by the reduced post-thawing motility of sperms compared to the effects of dilution and equilibration regardless of the concentration of antioxidant supplementation (Table 2). The addition of $\beta$-carotene could significantly $(\mathrm{P}<0.05)$ maintain the normal motility. Sperms diluted in egg yolk-tris based extenders containing $0.625 \%(\mathrm{w} / \mathrm{v}) \beta$-carotene $(\mathrm{P} 1)$ had better post-thawing motility $(50.2 \%)$ than those diluted in control extenders $(\mathrm{P} 0,42.6 \%)$ or extenders added with $1.25 \%(\mathrm{P} 2)$ and $2.5 \% \beta$-carotene (P3), $37.4 \%$ and $10.5 \%$, respectively.

As illustrated in Table 3, the addition of $\beta$-carotene maintained the viability of frozen spermatozoa of Aceh swamp buffalo. Addition of $0.625 \%(\mathrm{w} / \mathrm{v}) \beta$-carotene was sufficient to maintain the viability of spermatozoa after thawing $(57.8 \%)$, higher than those found in untreated control sperms $(55.0 \%)$ and those added with higher $\beta$-carotene concentrations [(1.25\%-2.5\%) $(31.2 \%$ and $15.0 \%$, respectively)].

Acrosomal integrity of spermatozoa of Aceh swamp buffalo was among aspects examined in this study. Results of this study showed that the addition of $\beta$-carotene could significantly $(\mathrm{P}<0.05)$ maintain the integrity of acrosomal cap of the spermatozoa. Sperms

Table 3. Average viability (\%) of sperms of Aceh swamp buffalo treated with various concentrations of $\beta$-carotene at different phases of semen processing

\begin{tabular}{ccccc}
\hline \multirow{2}{*}{ Treatments } & \multirow{N}{*}{ N } & \multicolumn{3}{c}{ Phases of semen processing } \\
\cline { 3 - 5 } & & Dilution & Equilibration & $\begin{array}{c}\text { Post } \\
\text { thawing }\end{array}$ \\
\hline P0 & 5 & $87.8 \pm 3.83^{\mathrm{b}}$ & $81.6 \pm 1.15^{\mathrm{b}}$ & $55.0 \pm 1.15^{\mathrm{c}}$ \\
P1 & 5 & $89.2 \pm 2.46^{\mathrm{b}}$ & $81.6 \pm 3.57^{\mathrm{b}}$ & $57.8 \pm 0.44^{\mathrm{c}}$ \\
P2 & 5 & $72.0 \pm 4.36^{\mathrm{a}}$ & $58.0 \pm 2.29^{\mathrm{a}}$ & $31.2 \pm 3.15^{\mathrm{b}}$ \\
P3 & 5 & $74.8 \pm 5.01^{\mathrm{a}}$ & $51.2 \pm 5.35^{\mathrm{a}}$ & $15.0 \pm 4.20^{\mathrm{a}}$ \\
\hline
\end{tabular}

Note: Means in the same column with different superscripts differ significantly $(\mathrm{P}<0.05)$. $\mathrm{P} 0=0 \% \beta$-carotene $(\mathrm{w} / \mathrm{v}) ; \mathrm{P} 1=0.625 \% \beta$-carotene $(\mathrm{w} / \mathrm{v}), \mathrm{P} 2=1.25 \% \beta$-carotene $(\mathrm{w} / \mathrm{v}) ; \mathrm{P} 3=2.5 \% \beta$-carotene $(\mathrm{w} / \mathrm{v})$. $\mathrm{N}=$ number of sample.

Table 4. Average acrosome integrity (\%) of sperms of Aceh swamp buffalo treated with various concentrations of $\beta$-carotene at different phases of semen processing

\begin{tabular}{ccccc}
\hline \multirow{2}{*}{ Treatments } & N & \multicolumn{3}{c}{ Phases of semen processing } \\
\cline { 3 - 5 } & & Dilution & Equilibration & $\begin{array}{c}\text { Post } \\
\text { thawing }\end{array}$ \\
\hline P0 & 5 & $85.1 \pm 5.28^{\mathrm{b}}$ & $72.5 \pm 3.86^{\mathrm{b}}$ & $52.0 \pm 4.58^{\mathrm{c}}$ \\
P1 & 5 & $88.2 \pm 4.01^{\mathrm{b}}$ & $85.3 \pm 2.18^{\mathrm{c}}$ & $58.6 \pm 0.83^{\mathrm{d}}$ \\
P2 & 5 & $62.0 \pm 3.36^{\mathrm{a}}$ & $67.0 \pm 1.92^{\mathrm{a}}$ & $34.4 \pm 1.20^{\mathrm{b}}$ \\
P3 & 5 & $70.6 \pm 3.71^{\mathrm{a}}$ & $66.2 \pm 5.06^{\mathrm{a}}$ & $24.0 \pm 2.15^{\mathrm{a}}$ \\
\hline
\end{tabular}

Note: Means in the same column with different superscripts differ significantly $(\mathrm{P}<0.05) . \mathrm{P} 0=0 \% \beta$-carotene $(\mathrm{w} / \mathrm{v}) ; \mathrm{P} 1=0.625 \% \beta$-carotene $(\mathrm{w} / \mathrm{v}), \mathrm{P} 2=1.25 \% \beta$-carotene $(\mathrm{w} / \mathrm{v}) ; \mathrm{P} 3=2.5 \% \beta$-carotene $(\mathrm{w} / \mathrm{v})$. $\mathrm{N}=$ number of sample. 
Table 5. Plasma membrane integrity (\%) of sperms of Aceh swamp buffalo treated with various concentrations of $\beta$-carotene at different phases of semen processing

\begin{tabular}{ccccc}
\hline \multirow{2}{*}{ Treatments } & \multirow{2}{*}{ N } & \multicolumn{3}{c}{ Phases of semen processing } \\
\cline { 3 - 5 } & & Dilution & Equilibration & $\begin{array}{c}\text { Post } \\
\text { thawing }\end{array}$ \\
\hline P0 & 5 & $82.0 \pm 4.68^{\mathrm{b}}$ & $79.8 \pm 7.94^{\mathrm{bc}}$ & $53.0 \pm 2.80^{\mathrm{c}}$ \\
P1 & 5 & $93.8 \pm 3.47^{\mathrm{c}}$ & $88.7 \pm 0.67^{\mathrm{c}}$ & $56.6 \pm 1.67^{\mathrm{d}}$ \\
P2 & 5 & $62.0 \pm 3.36^{\mathrm{a}}$ & $58.0 \pm 4.29^{\mathrm{a}}$ & $31.2 \pm 3.52^{\mathrm{b}}$ \\
P3 & 5 & $61.6 \pm 4.50^{\mathrm{a}}$ & $57.6 \pm 2.73^{\mathrm{a}}$ & $18.0 \pm 0.56^{\mathrm{a}}$ \\
\hline
\end{tabular}

Note: Means in the same column with different superscripts differ significantly $(\mathrm{P}<0.05) . \mathrm{P} 0=0 \% \beta$-carotene $(\mathrm{w} / \mathrm{v}) ; \mathrm{P} 1=0.625 \% \beta$-carotene $(\mathrm{w} / \mathrm{v}), \mathrm{P} 2=1.25 \% \beta$-carotene $(\mathrm{w} / \mathrm{v}) ; \mathrm{P} 3=2.5 \% \beta$-carotene $(\mathrm{w} / \mathrm{v})$. $\mathrm{N}=$ number of sample.

diluted in egg yolk-tris based extenders containing $0.625 \%(\mathrm{w} / \mathrm{v}) \beta$-carotene (P1) had better acrosome integrity $(58.6 \%)$ than those diluted in control extenders (P0, $52.0 \%$ ) or extenders added with $1.25 \%$ (P2) and $2.5 \%$ $\beta$-carotene (P3) $(34.4 \%$ and $24.0 \%$, respectively).

Plasma membrane integrity of spermatozoa of Aceh swamp buffalo was also examined in this study. The results showed that the addition of proper ammount of $\beta$-carotene could significantly $(\mathrm{P}<0.05)$ maintain the integrity of plasma membran of spermatozoa. Sperms diluted in egg yolk-tris based extenders containing $0.625 \%$ $(\mathrm{w} / \mathrm{v}) \quad \beta$-carotene (P1) had better plasma membrane integrity $(56.6 \%)$ than those diluted in control extenders (P0, 53.0\%) or extenders added with $1.25 \%$ (P2) and $2.5 \% \beta$-carotene (P3) $(31.2 \%$ and $18 \%$, respectively).

Frozen semen showing the best quality (P1) was used in the artificial insemination to find out its fertility in vivo. Here, 10 female buffaloes were estrous synchronized and then artificially inseminated by P1 semen. Pregnancy was obtained in 5 out of 10 females $(50.0 \%$.)

\section{DISCUSSION}

The availability of good frozen semen is among key factors for efficient application of artificial insemination. Freezing of buffalo semen, however, is challenged by poor freezeability that needs to be addressed by additional treatments such as a combination of appropriate cryoprotectants and antioxidants. In this study, the addition of antioxidants into extender containing proper ammount of cryoprotectant such as lactose and glycerol (Eriani et al., 2017) was intended to obtain a better quality of semen of Aceh swamp buffalo after freezing process. It was proposed that the addition of appropriate concentration of antioxidant $\beta$-carotene in egg yolk trisbased extenders could maintain the quality of spermatozoa after freezing. Semen quality was assessed based on post-thawed motility, viability, acrosomal integrity, and plasma membrane integrity of sperm of Aceh swamp buffalo fulfilling the standard cryopreservation requirement (Table 1).

The results of this study indicate that the addition of $\beta$-carotene with the proper concentration can improve the quality of frozen semen of Aceh swamp buffalo. The addition of $0.625 \%(\mathrm{w} / \mathrm{v}) \beta$-carotene produced frozen semen with a significantly higher quality (spermatozoa motility, acrosomal integrity, and plasma membrane integrity) than the control. This suggested that as an antioxidant compound, $\beta$-carotene could reduce lipid peroxidation reactions that can damage plasma membrane of spermatozoa.

Results obtained in this study were in agreement with those reported by Layek et al. (2016) that the addition of some antioxidants into egg yolk tris-based extenders can improve the frozen-semen quality of Boer goat. Similar results were also reported by Ansari et al. (2011) in their study using frozen semen of swamp buffalo and cow treated with glutathione supplementation. Other investigators, when using andromed extenders added with an appropriate amount of glutathione, also recorded a better quality of spermatozoa in Bali cattle (Syarifuddin et al., 2015).

The best concentration of $\beta$-carotene that could maintain the high post-thawing quality of sperms of Aceh swamp buffalo was $0.625 \%(\mathrm{w} / \mathrm{v})$. The addition of $\beta$-carotene in high concentrations, $1.25 \%$ and $2.5 \%(\mathrm{w} / \mathrm{v})$, resulted in a significantly lower quality of frozen semen of buffalo compared with the addition of $0.625 \%(\mathrm{w} / \mathrm{v})$ $\beta$-carotene. This effect is due to the increased osmotic pressure of semen extender, thus adversely affecting the process of metabolism. Disrupted metabolism process will result in the decreased energy production (ATP), which negatively affects the motility and survival of spermatozoa. Altogether, the results obtained indicated that the effects of appropriate concentration of antioxidant (in this case $\beta$-carotene) for maintaining semen quality.

The importance of appropriate antioxidant concentration for better semen quality was also reported by other investigators. In term of motility, Rizal (2005) found a better motility of Garut sheep sperms diluted in egg yolk tris-based diluents added with $0.1-0.2 \%$ $(\mathrm{w} / \mathrm{v}) \beta$-carotene compared to those diluted in extenders containing $0.3 \% \quad \beta$-carotene $(56.78 \%$ vs. $53.33 \%$ ). Additionally, Gunawan et al. (2012) showed that adding $0.002 \% \beta$-carotene into diluents could maintain postthawing motility of sperms in Bali cattle. However, the improved post-thawing motility of sperm was not found when the concentration of $\beta$-carotene was higher than $0.003 \%$. Andromed diluents added with $5 \%$ and $10 \%$ glutathione also produced a better spermatozoa motility in Bali cattle than control (Syarifuddin et al., 2015). Diluents added with glutathione of $0.05 \mathrm{mM}$ and 0.10 $\mathrm{mM}$ were also able to maintain the sperms motilities of cow higher than plain diluents without glutathione supplementation (Ansari et al., 2011; Memon et al., 2012).

Considering from viability, previous study using Garut sheep sperm indicated that extenders added with $0.002 \% \beta$-carotene resulted in a better spermatozoa viability $(56.78 \%)$ than those untreated control $(52.33 \%)$ or diluents containing $0.001 \%$ (52.89\%) and $0.003 \% \beta$-carotene (53.33\%) (Rizal, 2005). Similar result was also reported by Siahaan et al. (2012) when using spermatozoa of Bali cattle. Gunawan et al. (2012) stated that adding $0.002 \% \beta$-carotene could maintain a better spermatozoa viability of cow than that of untreated con- 
trol $(68.33 \%$ vs. $51.67 \%)$. However, the best $\beta$-carotene concentration i.e., $0.002 \%$, giving a good spermatozoa viability found in the previous studies (Gunawan et al., 2012) were lower than that found in this research. This results indicate that different species of animals have different response on sperms viability to $\beta$-carotene concentration.

Since part of the head structures of spermatozoa are equipped with essential enzymes for penetrating oocytes (Layek et al., 2016), intact acrosomal cap is crucial condition for fertilization. Acrosomal integrity, therefore, could become the best evaluation parameter for fertilization (Morrell et al., 2017). However, the effects of $\beta$-carotene addition in semen diluents on acrosomal integrity have not been widely reported. We found that acrosomal integrity of post-thawed sperms of Aceh swamp buffalo treated with $0.625 \%$ $(\mathrm{w} / \mathrm{v}) \quad \beta$-carotene $(58.6 \%)$ was significantly better $(p<005)$ than those treated with $1.25 \%(\mathrm{w} / \mathrm{v}) \beta$-carotene $(34.4 \%), 2.50 \%(\mathrm{w} / \mathrm{v}) \beta$-carotene $(24.0 \%)$, and untreated control $(52.0 \%)$. These results are supported by data from Rizal (2005) showing a better acrosome integrity in the spermatozoa of Garut sheep treated with $0.002 \%$ $\beta$-carotene, 5\% glutathione, and 10\% glutathione than those of untreated control (51.00\% vs. $47.11 \%, 54.22 \%$ vs. $47.11 \%$, and $54.00 \%$ vs $47.11 \%$, respectively). Ansari et al. (2011) added that the addition of $0.5 \mathrm{mM}$ glutathione could maintain acrosome integrity of sperm in Pakistan swamp buffalo stored at $5^{\circ} \mathrm{C}$ for 3 days up to $86.3 \%$, that was significantly higher than those recorded in control group $(84.0 \%)$.

Addition of appropriate concentration of $\beta$-carotene to egg yolk-tris based extenders also resulted in a better protection for the integrity of plasma membrane of sperms. Average plasma membrane integrity of sperms in Aceh swamp buffalo treated with $0.625 \%$ $(\mathrm{w} / \mathrm{v}) \beta$-carotene $(56.6 \%)$ was significantly better $(\mathrm{P}<0.05)$ than that of untreated control $(53.0 \%)$ and those of treated with $1.25 \%(\mathrm{w} / \mathrm{v}) \beta$-carotene $(31.2 \%)$ and $2.5 \%(\mathrm{w} / \mathrm{v})$ $\beta$-carotene $(18.0 \%)$. The same pattern was also found in using $0.5 \mathrm{mM}, 1.0 \mathrm{mM}$, and $2.0 \mathrm{mM}$ hydroxytoluene antioxidants to the same extenders (Memon et al., 2011).

Altogether the results described above support the facts that adding appropriate concentration of antioxidants enhances post-thawing quality of sperms as is indicated by a better sperms motility, viability, acrosomal integrity, and plasma membrane integrity. During freezing processing, semen experiences exogenous stressors triggering higher cells metabolisms that eventually result in higher oxygen consumption. Radical metabolic wastes such as ROS and hydrogen peroxides are among the by-products of increased oxygen use to provide energy (ATP) for higher rates of metabolic pathways (Simmons, 2011). These reactive compounds might result in membrane damages from lipid peroxidation reactions. According to Rizal (2005), these are situations where antioxidants such as $\beta$-carotene and glutathione play their roles in blocking the chain reaction of lipid peroxidation by transferring one electron to the radical compounds or by accepting electron to form safer metabolites. These processes will prevent the potential detrimental effects of free radicals on the plasma membrane of cells, including spermatozoa. $\beta$-carotene is a fat-soluble antioxidant capable of cutting of lipid peroxide chain reactions occurred in the plasma membrane of cells triggered by the presence of ROS (Bucak et al., 2010b). According to Pryor et al. (2002), $\beta$-carotene is a good antioxidant for blocking free radicals because it tends to undergo oxidation as compared to any saturated lipids. Glutathione, on the other hand, is a sulfhydryl compound with antioxidant, antitoxic, and enzyme co-factor potentials. The effect of maintaining sperm viability is probably related to its ability to control homeostatic of intracellular and extracellular fluids (Uysal et al., 2007). Glutathione supplementation, therefore, increases spermatozoa viability by reducing the plasma membrane damages.

More evidences have been collected in in vitro and in vivo experiments regarding to the benefits of antioxidant administration on living cells or the body. Supplementation of the compounds in extenders for preparing frozen sperms, however, should be done in an appropriate concentration since the presence of higher antioxidants might reduce the quality of spermatozoa. Excessive levels of $\beta$-carotene supplementation, for example, might be toxic because of the naturally low level of $\beta$-carotene contents in the living cells (Sariözkan et al., 2014). Excessive addition of glutathione might be detrimental in coping with cold shock. Higher glutathione concentration might lead to a higher osmotic pressure that in turn causing a decreased spermatozoa viability. Ideal glutathione concentrations for maintaining the quality of spermatozoa after freezing are from low to medium.

The most significant obstacle to utilize cryopreserved semen of many species is that cooling, freezing, and thawing damage sperm membrane structures, leading to a fewer number of viable and motile cells after thawing process (Morrell et al., 2017). Research on the damage of spermatozoa after freezing and thawing have been previously reported on some domestic animals such as bull (Ting-xi et al., 2016), ram (Toker et al., 2017), stallion (Krakowski et al., 2013), and boar (Yeste et al., 2014). It was suggested that some factors involved in sperm transportation and fertilization in the reproduction track of female animals could prevent the benefit of using higher quality semen to get higher fertilization rate. This process required the semen to adapt from frozen state to a warmer environment condition. In addition, cryopreservation can cause the damage of DNA (Eveson, 2016). Consequently, the fertility following AI using cryopreserved semen is lower than that of using fresh semen in most species. In this study, appreciable rate of buffalo pregnancy (50\%) was obtained using frozen semen of Aceh swamp buffalo treated with $0.625 \%$ $(\mathrm{w} / \mathrm{v}) \quad \beta$-carotene. The motility, viability, acrosome integrity, and plasma membrane integrity of frozen semen treated with $0.625 \% \beta$-carotene were $50.2 \%, 57.8 \%$, $58.6 \%$, and $56.6 \%$, respectively. The pregnancy rate obtained was lower than the result reported by Sianturi et al. (2012) that found $77.8 \%$ in West Java's swamp buffaloes. However, the result was equal to that found in previous studies with pregnancy rate of $40 \%-60 \%$ (Batista et al., 2009; Yulnawati et al., 2013). Even in anoa, 
the post AI pregnancy rate was 25\% (Judi et al., 2012) that was lower than result found in this study.

\section{CONCLUSION}

Adminstiration of $0.65 \% \quad(\mathrm{w} / \mathrm{v})$ antioxidant $\beta$-carotene has a capability and protective effect on motility, viability, acrosomal integrity, and plasma membrane integrity of frozen-thawed sperms of Aceh swamp buffalo that are good for artificial insemination.

\section{Implication}

Overall, the results of this study showed the potential use of frezing technique and antioxidant supplementation for obtaining frozen semen of Aceh swamp buffalo fulfiling requirement for success artifical insemination. In the future, results of this study can be used to enhance the genetic quality of Aceh buffalo and increase its population. Indirectly this application can lead to improvement of local community livelihood from the increased meat production.

\section{ACKNOWLEDGEMENT}

Authors thank the Research Institute of Syiah Kuala University and 7 in 1 IDB Project who funded this study under the scheme Penelitian Unggulan Perguruan Tinggi (PUPT) with contract No. 137/UN11.2/ PP/SP2/2016. This research is partially funded by PNBP FMIPA Universitas Syiah Kuala 2017.

\section{REFERENCES}

Almbro, M., D. K. Dowling, \& L. W. Simmons. 2011. Effects of vitamin $\mathrm{E}$ and beta-carotene on sperm competitiveness. J. Ecology Letters. 14:891-895 https://doi.org/10.1111/j.1461-0248.2011.01653.x

Ansari, M.S., B. A. Rakha, N. Ullah, S. M. H. Andrabi, \& S. Akhter. 2011. Glutathione addition of cooled buffalo (Bubalus bubalis) bull semen. Pakistan J. Zool. 43(Suppl. 1):49-55.

Asadpour, R. M. M. Pourseif, \& G. Moghadam. 2012. Effect of vitamin B12 addition to extenders on some physicochemical parameters of semen in crossbred rams. African. J. Biotechnol. 54:11741-11745.

Bansal, A.K., \& G. S. Bilaspuri. 2011. Impacts of oxidative stress and antioxidants on semen functions. Vet. Med. Int. 2011:1-7. https://doi.org/10.4061/2011/686137

Batista,M.,T.Nino,D.Alamo,N.Castro,M.Santana,F.Gonzalez, F. Cabrera, \& A. Gracia. 2009. Successful artificial insemination using semen frozen and stored by an ultrafreezer in the Majorera goat breed. Theriogenology 71:1307-1315. https://doi.org/10.1016/j.theriogenology.2008.12.024

BPS (Central Statistical Board) of Indonesia. 2016. https:// www.bps.go.id/linkTableDinamis/view. Accessed on August 20th, 2017

Bucak, M.N., P. B. Tuncer, S. Sariözkan, N. Baspinar, M. Taspinar, K. Coyan, A. Bilqili, P. P. Alkalin, S. Büyükleblebici, S. Aydos, S. Ilgaz, A. Sunguroğlu, \& D. Oztuna. 2010a. Effects of antioxidants on postthawed bovine sperm and oxidative stress parameters: antioxidants protect DNA integrity against cryodamage. Cryobiology. 61(Suppl. 3):248-53. https://doi.org/10.1016/j. cryobiol.2010.09.001
Bucak, M.N., S. Sariözkan, \& P. B. Tuncer. 2010b. The effect of antioxidants on post-thawed Angora goat (Capra hircus ancryrensis) sperm parameters, lipid peroxidation and antioxidant activities. Small Rumin Res. 89(Suppl.1):24-30. https://doi.org/10.1016/j.smallrumres.2009.11.015

Cruz, L. C. 2007. Trends in buffalo production in Asia. Italian J. Anim. Sci. 6(Suppl. 2): 9-24. https://doi.org/10.4081/ ijas.2007.s2.9

Eriani, K.,M. Ihdina, R. Rosnizar, D. Dasrul, S. Suhartono, \& M. Rizal. 2017a. Cryopreservation of Aceh swamp buffalo (Bubalus bubalis) semen with combination of glyserol and lactose. Biosaintifika. 9(Suppl 3):409-416. https://doi. org/10.15294/biosaintifika.v9i3.11426

Eriani, K.,N. Sari, M. Ihdina, \& Rosnizar. 2017b. The effect of equilibration time on semen freezing of local swamp buffalo (Bubalus bubalis) with combination extender of lactose and glycerol. Nus Biosci. 9(Suppl 1):77-82. https://doi. org/10.13057/nusbiosci/n090113

Eveson, D. P. 2016. The Sperm Chromatin Structure Assay (SCSA $\AA$ ) and other sperm DNA fragmentation tests for evaluation of sperm nuclear DNA integrity as related to fertility. Anim. Reprod. Sci. 169:56-75. https://doi. org/10.1016/j.anireprosci.2016.01.017

Fang, Y.I., R. Zhonga, L. Chenb, C. Feng, H. Suna, \& D. Zhoua. 2015. Effects of astaxanthin supplementation on the sperm quality and antioxidant capacity of ram semen during liquid storage. Small. Rumin. Res.130:178-182 https://doi.org/10.1016/j.smallrumres.2015.05.016

Gunawan, I., D. N. Laksmi, \& D. I. Trilaksana. 2012. The effectiveness of the addition of b-carotene and glutathione in diluent materials to sperm motility and viability at cryopreservation semen cattle. Indonesia. Med. Vet. 1(Suppl. 3):385.

Holt, W. V. 2000. Fundamental aspects of sperm cryobiology: the importance of species and individual differences. Theriogenology. 53:4758. https://doi.org/10.1016/S0093-691X(99)00239-3

Judi, T. L. Yusuf, B. Purwantara, D. Sajuthi, M. Agil, J. Manangsang, R. Sudarwati, Y. T. Hastuti, B. Huaso, A. Widianti, \& S. Prastitic. 2012. Successful intracervical insemination and characteristics of anoa (Bubalus sp.) parturation behavior in captivity. J. Med. Pet. 32(Suppl. 2):73-79. https://doi.org/10.5398/medpet.2012.35.2.73

Kasimanickam, R., V. Kasimanickam, K. D. Pelzer, \& J. J. Dascanio. 2007. Effect of breed and sperm concentration on the changes in structural, functional and motility parameters of ramlamb spermatozoa during storage at $4^{\circ} \mathrm{C}$. Anim Reprod Sci. 101:60 -73. https://doi.org/10.1016/j. anireprosci.2006.09.001

Krakowski, L., J. Obara, A. Wachocka, T. Piech, P. Bartoszek, K. Kostro, \& M. R. Tatara. 2013. Assessment of extent of apoptosis and DNA defragmentation in chilled semen of stallions during the breeding season. Reprod. Domest. Anim. 48:826-832. https://doi.org/10.1111/rda.12170

Kumaresan, A., M. R. Ansari, \& G. Abhishek. 2005. Modulation of post-thaw sperm functions with oviductal proteins in buffaloes. Anim. Reprod. Sci. 90:73-84. https://doi.org/10.1016/j.anireprosci.2005.01.009

Layek, S. S., T. K. Mohanty, A. Kumaresan, \& J. E. Parks. 2016. Cryopreservation of bull semen: evolution from egg yolk based to soybean based extenders. Anim. Reprod. Sci. 172:1-9. https://doi.org/10.1016/j.anireprosci.2016.04.013

Marti, J. I., E. Marti, J. A. Cebrian-Perez, \& T. Muino Blanco. 2003. Survival rate and antioxidant enzyme activity of ram spermatozoa after dilution with different extenders or selection by a dextran swim-up procedure. Theriogenology. 60:1025-1037. https://doi.org/10.1016/S0093-691X(03)00105-5 
Memon, A.A., H. Wahid, Y. Rosnina, Y. M. Goh, M. Ebrahimi, F. M. Nadia, \& G. Audrey. 2011. Effect of butylated hydoxytoluene on cryopreservation of boer goat semen in tris egg yolk extender. Anim. Reprod. Sci. 129:44-49. https://doi.org/10.1016/j.anireprosci.2011.10.004

Memon, A. A., H. Wahid, Y. Rosnina, Y. M. Goh, M. Ebrahimi, \& F. M. Nadia. 2012. Effect of antioxidants on post thaw microscopic, oxidative stress parameter and fertility of boer goat spermatozoa in tris egg yolk glycerol extender. Anim. Reprod. Sci. 136:55-60. https://doi.org/10.1016/j. anireprosci.2012.10.020

Morrell, J. M., T. Nongbua, S. Veleanu, I. L. Verde, K. Lundstedt-Enkel, A. Edman, \& A. Johannisson. 2017. Sperm quality variables as indicators of bull fertility may be breed dependent. Anim. Reprod. Sci. 185:42-52. https://doi.org/10.1016/j.anireprosci.2017.08.001

Oshima, S. F., H. Ojima, Y. Sakamoto, Ishiguro, \& J. Terao. 1993. Inhibitory effect of -carotene and asthaxanthin on phorosensitizied oxidation of phospolipid bilayers. Nur. Sci. Vitaminol. 39(Suppl. 3):607-615. https://doi. org/10.3177/jnsv.39.607

Pryor, W. A., W. Stahl, \& C. L. Roch. 2000. $\beta$-Carotene: from biochemistry to clinical trials. Nutr. Rev.58:39-53. https:// doi.org/10.1111/j.1753-4887.2000.tb07810.x

Rizal, M. 2005. Effectivity various concentrations of $\beta$-carotene on the quality of frozen Garut sheep semen. Anim. Prod. 7(Suppl. 1):6-13

Sariözkan, S., M. N. Bucak, P. B. Tuncer, S. Buyukleblebici, \& F. Canturk. 2014. Influence of various antioxidants added to TCM-199 on post-thaw bovine sperm parameters, DNA integrity and fertilizing ability. Cryobiology. 68:129-133. https://doi.org/10.1016/j.cryobiol.2014.01.007

Sariözkan, S., P. B. Tuncer, M. N. Bucak, \& P. A. Ulutas. 2009. Influence of various antioxidants on microscopicoxidative stress indicators and fertilizing ability of frozen-thawed bull semen. ACTA VET. BRNO. 78:463-469. https://doi.org/10.2754/avb200978030463

Sarsaifi, K., H. Y. Rosnina, O. M. Ariff, H. A. Wahid, H. Hani, N. Yimer, S. W. Naing, \& M. O. Abas. 2013. Effects of semen collection methods on the quality of pre and post thawed Bali cattle (Bos javanicus) spermatozoa. Reprod. Domest. Anim. 44(Suppl. 6):1006-1012. https://doi.org/10.1111/ rda.12206

Siahaan, E. A., D. N. D. I.Laksmi, \& W. Bebas. 2012. Efectivity of addition of various concentration $\beta$-carotene on motility and viability of Bali cattle spermatozoa post thawing. Indonesia.Med.Vet.1(Suppl 2):239-251.
Sianturi, R. G., B. Purwantara, I. Supriatna, Amrozi, \& P. Situmorang. 2012. Optimasi inseminasi buatan pada kerbau lumpur (Bubalus bubalis) melalui teknis sinkronisasi estrus dan ovulasi. JITV. 17(Suppl 2):92-99.

Simmons, L. W. 2011. Effects of vitamins E and beta-carotene on sperm competitiveness. Ecology Letters. 14:891-895. https://doi.org/10.1111/j.1461-0248.2011.01653.x

Singh, J., A. S. Nanda, \& G. P. Adams. 2000. The reproductive pattern efficiency of female. Anim. Reprod. Sci. 60(Suppl. 61):593-604. https://doi.org/10.1016/S0378-4320(00)00109-3

Syarifuddin, A., N. D. I. L. Desak, \& B. Wayan. 2012. Effectiveness of the addition of various $\beta$-carotene concentrations to motility and viability of Bali cattle spermatozoa post thawing. Indonesia. Med. Vet. 1(Suppl. 2):173-185.

Ting-xi, H. U., Z. H. U. Hua-bin, S. U. N. Wei-jun, H. A. O Hai-sheng, Z. H. A. O. Xue-ming, D. U. Wei-hua, \& W. A. N. G. Zong-li. 2016. Sperm pretreatment with glutathione improves IVF embryos development through increasing the viability and antioxidative capacity of sexsorted and unsorted bull semen. Integrative Agriculture. 15(Suppl. 10):2326-2335. https://doi.org/10.1016/ S2095-3119(16)61402-8

Toker, M. B., S. Alcay, E. Gokce, \& B. Ustuner. 2017. Cryopreservation of ram semen with antioxidant supplemented soybean lecithin-based extenders and impacts on incubation resilience. Cryobiology. 72:205-209. https://doi. org/10.1016/j.cryobiol.2016.05.001

Uysal, O., M. N. Bucak, I. Yavas, \& O. Varish. 2007. Effect of various antioxidantson the quality of frozen-thawed bull semen. J. Anim. Vet. Adv. 6(Suppl. 12):1362-1366

Wanapat, M., \& V. Chanthakhoun. 2015. Buffalo production for emerging market as a potential animal protein source for global population. Buffalo Bull. 34(Suppl. 2): 164-180.

Wang, X., R. K. Sharma, S. C. Sikka, A. J. Thomas Jr, T. Falcone, \& A. Agarwal. 2003. Oxsidative stress is associated with increased apoptosis leading to spermatozoa DNA damage in patients eith male factor infertility. Fertil. Steril. 80:531-535 https://doi.org/10.1016/S0015-0282(03)00756-8

Yeste, M., E. Estrada, E. Pinart, S. Bonet, J. Miro, \& J. E. Rodriguez-Gil. 2014. The improving effect of reduced glutathione on boar sperm cryotolerance is related with the intrinsic ejaculate freezability. Cryobiology. 68:251-261. https://doi.org/10.1016/j.cryobiol.2014.02.004

Yulnawati, Y., H. Maheshwari, M. Rizal, \& A. Boediono. 2013. The success rate of artificial insemination using post-thawed spotted buffaloes epididymal sperm. J. Met. Pet. 36(Suppl. 2):101-105. https://doi.org/10.5398/ medpet.2013.36.2.101 